\title{
Novice English Teachers' Learning to Teach
}

\author{
Bin Chen \\ School of Foreign Language \\ Wuhan Institute of Technology \\ Wuhan, Hubei province, China \\ e-mail: apple163@163.com
}

\author{
Yuanyuan Zhang \\ School of Foreign Language \\ Wuhan Institute of Technology \\ Wuhan, Hubei province, China
}

\begin{abstract}
Novice teachers' learning to teach process is hard yet rewarding. To probe Chinese middle school novice English teachers' condition of learning to teach, a questionnaire focused on four aspects was implemented. Results of the questionnaire showed that most novice English teachers investigated were not satisfied with their learning to teach process, and they felt overwhelmed and exhausted both in teaching and student discipline. They needed better collaborative teaching environment, and being trained to develop a habit of reflecting on their teaching activities. On the basis of the study, suggestions were offered.
\end{abstract}

Keywords-novice English teachers; condition of learning to teach; suggestion

\section{INTRODUCTION}

Teacher educators agree that learning to teach is a process although they have different conceptions on it. Richter et al. (2011) claim that novice teachers' first 3 years of the teaching experience is a time of "survival and discovery". To investigate novice teachers' learning to teach can provide teacher educators much food for thought in making or revising pre-service teacher education programmes. Kagan (1990) states that a successful programme of pre-service teacher education should be set in a framework where conceptions of teaching and learning are based on theories and supported by researches. Our study aimed at investigating novice English teachers' feelings on learning to teach, collaborative and reflective efforts and urgent need, and at providing suggestions on the basis of the study in expectation that there will be big difference in preparing pre-service and novice teachers for learning to teach in future.

\section{LITERATURE REVIEW}

Russell et al (2001) claim that the design and delivery of the innovative pre-service teacher education programme should contain the premise that pre-service teachers' thinking like a teacher is a process that must be explicitly taught by teacher educators and developed over time, that collaboration efforts for novice teachers' induction are at many levels within a collaborative setting, such as collaboration between school and university, mentor and mentored teacher etc. Burton (2009) says that most teacher educators agree that reflection is a necessary tool in novice teachers' professional development. Farrell (2008) argues that, by reflective practice, teachers can improve their own teaching. However, some researchers claim that novice teachers usually view their first 3 years of teaching as a struggle for survival (Day et al.2007; Veenman, 1984). There is few published survey on how novice English teachers in Chinese middle schools switch to qualified teachers, so it is significant to investigate novice English teachers' learning to teach.

\section{DESIGN AND METHOD}

The present author adopted questionnaire to collect data, and used the qualitative approach to analyze the data. And discussion and suggestions were provided in the study.

\section{A. Subjects}

Thirty subjects were novice English teachers of junior and senior middle schools in different provinces of China. And they were in their first induction year. They were offered master degree in June, 2014 after they finished twoyear full-time pre-service teacher education programme for postgraduates. They were Chinese coming from different provinces of China. Their average age was 24 years old. The subjects consisted of $24(80 \%)$ females and $6(20 \%)$ males.

\section{B. Instrument}

The instrument of the present study was a 10-item questionnaire. It was designed by the present author. There was one open-ended question and nine closed questions that required subjects to circle one answer from the multiple choices: strongly disagree (SD), disagree (D), neither agree nor disagree $(\mathrm{N})$, agree $(\mathrm{A})$, strongly agree $(\mathrm{SA})$.

\section{Research Procedure}

The questionnaires were hand out to the subjects by the present author through e-mail. They were asked to fill out the questionnaire with instructions about how to fill out it in order to get rid of confusion. After collecting questionnaire in time, the present author made the census and descriptive analysis of the data. For instance, percentage was used. Based on the discussion of the data, suggestions were offered.

\section{DATA ANALYSIS}

The present author distributed 30 Questionnaires to the subjects, and 30 returned Questionnaires were valid. Items of the questionnaire and their functions are showed in "Table 1", 
data of the open-ended question are in "Table 2", and data of the closed questions are in "Table 3". These tables are as follows:

TABLE I. ITEMS OF THE QUESTIONNAIRE AND THEIR FUNCTION

\begin{tabular}{|c|c|}
\hline Items & $\begin{array}{l}\text { Functions of the } \\
\text { Items }\end{array}$ \\
\hline $\begin{array}{l}\text { 1. I usually feel pleasant in the learning to } \\
\text { teach process for I seldom meet problems } \\
\text { relating to teaching approach and practice, } \\
\text { student discipline. }\end{array}$ & \multirow[t]{3}{*}{$\begin{array}{l}\text { 1. novice teachers' } \\
\text { feeling on the } \\
\text { learning to teach } \\
\text { process. }\end{array}$} \\
\hline $\begin{array}{l}2 . \text { I usually feel overwhelmed and } \\
\text { exhausted in the learning to teach process } \\
\text { for I meet problems with teaching approach } \\
\text { and practice. }\end{array}$ & \\
\hline $\begin{array}{l}\text { 3. I usually feel overwhelmed and } \\
\text { exhausted in the learning to teach process } \\
\text { for I meet problems with student discipline } \\
\text { and continuous trial and error. }\end{array}$ & \\
\hline $\begin{array}{l}\text { 4. I am satisfied with learning from others } \\
\text { involved in the learning to teach process, } \\
\text { such as mentors, colleague teachers and } \\
\text { teacher educators. }\end{array}$ & \multirow[t]{3}{*}{$\begin{array}{l}\text { 2. novice teachers' } \\
\text { collaborative effort in } \\
\text { the learning to teach } \\
\text { process }\end{array}$} \\
\hline $\begin{array}{l}\text { 5. In the learning to teach process, I can get } \\
\text { more help from mentors than from } \\
\text { colleague teachers and teacher educators. }\end{array}$ & \\
\hline $\begin{array}{l}\text { 6. In the learning to teach process, I seldom } \\
\text { have opportunity to attend conferences and } \\
\text { workshops. }\end{array}$ & \\
\hline $\begin{array}{l}\text { 7. I usually write reflective teaching diary } \\
\text { so that I can improve my teaching. }\end{array}$ & \multirow{3}{*}{$\begin{array}{l}\text { 3. novice teachers' } \\
\text { reflective effort in the } \\
\text { learning to teach } \\
\text { process }\end{array}$} \\
\hline $\begin{array}{l}\text { 8. I usually invite my peer teacher to } \\
\text { observe my teaching, and then to comment } \\
\text { on it. }\end{array}$ & \\
\hline $\begin{array}{l}\text { 9. When I think about my classroom } \\
\text { activities and alternative means of } \\
\text { achieving teaching aims after class, I can } \\
\text { find a solution to the dilemmas of } \\
\text { classroom practice I met. }\end{array}$ & \\
\hline $\begin{array}{l}\text { 10. What's your urgent need in improving } \\
\text { novice teachers' learning to teach process? }\end{array}$ & $\begin{array}{l}\text { novice teachers' } \\
\text { urgent need in } \\
\text { improving } \\
\text { learning to teach } \\
\text { process }\end{array}$ \\
\hline
\end{tabular}

TABLE II. DATA OF THE OPEN-ENDED QUESTION FROM THE QUESTIONNAIRE

\begin{tabular}{|l|l|}
\hline \multicolumn{1}{|c|}{ Urgent need } & Percentage \\
\hline $\begin{array}{l}\text { Teacher educators and middle school administrators } \\
\text { should attach importance to novice teachers' } \\
\text { learning to teach process. }\end{array}$ & $60 \%$ \\
\hline $\begin{array}{l}\text { Middle school administrators organize discussion } \\
\text { and activities targeting classroom management and } \\
\text { student discipline for novice teachers. }\end{array}$ & $76.7 \%$ \\
\hline $\begin{array}{l}\text { Offering novice teachers formal and informal } \\
\text { learning opportunities to learn to construct student- } \\
\text { centred/learning-oriented teaching practice. }\end{array}$ & $73.3 \%$ \\
\hline $\begin{array}{l}\text { Have opportunity to attend formal activities such as } \\
\text { conferences, workshops and peer observation. }\end{array}$ & $83.3 \%$ \\
\hline $\begin{array}{l}\text { Providing discussion on how to apply teaching } \\
\text { theory to classroom teaching practice. }\end{array}$ & $56.7 \%$ \\
\hline $\begin{array}{l}\text { Helping novice teachers to feel their work more } \\
\text { rewarding and their efforts more successful. }\end{array}$ & $66.7 \%$ \\
\hline
\end{tabular}

\section{RESULTS AND DISCUSSION}

\section{A. Results of the Questionnaire}

The results of the questionnaire "Table 3" showed that most of subjects felt overwhelmed and exhausted in the learning to teach process, for $70 \%$ of the them had problems with teaching approach and practice, $80 \%$ of them met problems with student discipline and continuous trial and error, and $83.4 \%$ of them did not feel pleasant in the learning to teach process for they often met problems relating to teaching approach and practice, student discipline. Only 10\% of them felt pleasant in the learning to teach process for they seldom met problems relating to teaching approach and practice, student discipline, $20 \%$ of them had no problems with teaching approach and practice, and $13.4 \%$ of them did not meet problems with student discipline and continuous trial and error.

Regarding novice teachers' collaborative effort in the learning to teach process, Data from the questionnaire "Table 3 " suggested that only $20 \%$ of the subjects were satisfied with it because $90 \%$ of the subjects only got help from mentors, and $93.4 \%$ subjects seldom have opportunity to attend conferences and workshops. However, $73.3 \%$ of them were not satisfied with learning from others involved in the learning to teach process, such as mentors, colleague teachers and teacher educators, and merely $6.6 \%$ of them got opportunity to attend conferences and workshops.

Concerning novice teachers' reflective effort in the learning to teach process, data of the questionnaire (Table 3) demonstrated that $83.3 \%$ of the subjects were not accustomed to writing reflective teaching diary, $77.7 \%$ of the subjects didn't invite their peer teacher to observe and comment on their teaching. And only $30 \%$ of the subjects could find a solution to the dilemmas of classroom practice by thinking about their classroom activities after class. Only $13.4 \%$ of them usually wrote reflective teaching diary to improve their teaching, merely $16.6 \%$ of them usually invite their peer teacher to observe their teaching, and then to comment on it, and $60 \%$ of them would not think about their classroom activities and alternative means of achieving teaching aims after class and find a solution to the dilemmas of classroom practice they met.

TABLE III. DATA OF THE Closed QUESTIONS FROM THE QUESTIONNAIRE

\begin{tabular}{|l|l|l|l|l|l|}
\hline \multirow{2}{*}{ Items } & \multicolumn{5}{|l}{ Percentage } \\
\cline { 2 - 6 } & $\boldsymbol{S D}$ & $\boldsymbol{D}$ & $\boldsymbol{N}$ & $\boldsymbol{A}$ & $\boldsymbol{S} \boldsymbol{A}$ \\
\hline 1 & $66.7 \%$ & $16.7 \%$ & $6.7 \%$ & $6.7 \%$ & $3.3 \%$ \\
\hline 2 & $13.3 \%$ & $6.7 \%$ & $10 \%$ & $16.7 \%$ & $53.3 \%$ \\
\hline 3 & $6.7 \%$ & $6.7 \%$ & $6.7 \%$ & $10 \%$ & $70 \%$ \\
\hline 4 & $63.3 \%$ & $10 \%$ & $6.7 \%$ & $6.7 \%$ & $13.3 \%$ \\
\hline 5 & $3.3 \%$ & $3.3 \%$ & $3.3 \%$ & $10 \%$ & $80 \%$ \\
\hline 6 & $3.3 \%$ & $3.3 \%$ & 0 & $6.7 \%$ & $86.7 \%$ \\
\hline 7 & $70 \%$ & $13.3 \%$ & $3.3 \%$ & $6.7 \%$ & $6.7 \%$ \\
\hline 8 & $67.7 \%$ & $10 \%$ & $6.7 \%$ & $3.3 \%$ & $13.3 \%$ \\
\hline 9 & $53.3 \%$ & $6.7 \%$ & $10 \%$ & $10 \%$ & $20 \%$ \\
\hline
\end{tabular}

a. Note: strongly disagree (SD), disagree (D), neither agree nor disagree $(\mathrm{N})$, agree (A), strongly agree (SA). 
In terms of novice teachers' urgent need in improving the learning to teach process, data of the questionnaire "Table 2 " displayed that $60 \%$ of the subjects required that teacher educators and middle school administrators attach importance to novice teachers' learning to teach process, $76.7 \%$ of them hoped that Middle school administrators organize discussion and activities targeting classroom management and student discipline for novice teachers, $73.3 \%$ of the subjects requested being offered formal and informal learning opportunities to learn to construct studentcentered or learning-oriented teaching practice, $83.3 \%$ of the subjects asked for opportunity to attend formal activities such as conferences, workshops and peer observation, 56.7\% of the subjects wished to be provided discussion on how to apply teaching theory to classroom teaching practice, $66.7 \%$ of the subjects needed the feeling of their work more rewarding and their efforts more successful.

\section{B. Discussion on the Result}

The results of the questionnaire indicated that, in general, as novice teachers, subjects were not satisfied with their learning to teach process. For, on the one hand, they felt overwhelmed and exhausted in the learning to teach process, which accords with the research result of Day et al.( 2007); on the other hand, they hadn't good collaborative teaching environment, and did not form a habit of reflecting on their teaching activities.

However, learning to teach is a hard yet rewarding process, during which novice teachers should learn to construct their own teaching approaches based on the theories they learned in universities. Their experience of choosing material, discussion on what to teach, how to teach and theoretical reasons for their teaching help them to understand the concept of learning to teach, which is a kind of experience of collaborative effort. To create collaborative environments can help smooth obstacles they met in teaching. It can be set up within peer teachers, between school and university, and among teacher educators, mentors. So learning to teach is a collaborative effort for them.

Meanwhile, Reflective teaching is a contemporary theme in foreign language teaching. Generally speaking, by reflecting on one's own teaching activities to improve his teaching and his students' learning, teachers can grow professionally. Reflective practice, especially critical ones, has the potential to help novice teachers to learn to teach. Approaches to critical reflection include peer observation and comments, written accounts of experiences, self-reports, autobiographies, journal writing, collaborative diary keeping and recording lessons etc. When novice teachers think about what happens in their classroom activities, and about alternative means of achieving goals or aims after class, they may find a solution to the dilemmas of classroom practice they meet. More often than not, reflection results in more questions and clearer perceptions on themselves and better plans for solving individual problems. It is through reflection that novice teachers focus on their concerns, come to better understand their own teacher behavior, and help themselves improve teaching effects. Those who can reflectively think and feel will find their work more rewarding and their efforts more successful.

As Corcoran (2007) states, the induction programs for novice teachers is necessary in order to create a collaborative teaching environment. And the habit of reflecting on one's own teaching activity can be taught and developed through the two-year full-time pre-service teacher education programme and the induction programs in order to improve novice teachers' learning to teach process.

\section{Suggestions on Novice English Teachers' Learning to Teach Process}

With the reform of English teaching in China, qualified middle school English teachers are needed urgently. Novice English teachers graduating from two-year full-time preservice teacher education programme aught to be the main team members of English teachers. Here are some suggestions on improving novice English teachers' learning to teach process.

Firstly, the two-year full-time pre-service English teacher education programme aught to contain courses set to teach student teachers how to teach English in middle school with examples, such as comment on English teaching plan, middle school teachers' English teaching videos and so on.

Secondly, teacher educators and mentors may try to provide more teaching chances for student teachers' practicum, and guide them to make progress in classroom teaching, like constructing learner-centered teaching practice and students' management etc.

Thirdly, teacher educators may train pre-service English teachers' habit of writing reflective diary, and help them reap benefits of reflective diary for improving teaching in practicum.

Fourthly, educational authorities can manage to provide induction programs for novice teachers in order to create a collaborative teaching environment, such as offering novice teachers with professional mentors, study groups, classroom observations and so on.

Lastly, administrators of middle schools should provide novice teachers opportunity to attend formal conferences, workshops and peer observation, and organize critical seminars on applying teaching theory to classroom teaching practice, classroom management and student discipline so that they could become open-minded to new perspectives and responsible for learners and decision-making, and researchers.

\section{CONCLUSION}

\section{A. Main Findings}

The main findings based on the study are as follows: most novice English teachers investigated were not satisfied with their learning to teach process, and they felt overwhelmed and exhausted both in English teaching and student discipline. They needed better collaborative teaching environment, and being trained to develop a habit of 
reflecting on their teaching activities so that they could obtain a sense of accomplishment and discovery in learning to teach process.

\section{B. Limitations and Suggestions on Future Research}

The present research unavoidable had limitations, like small sample size, without class observation and interview etc. And some suggestions are provided for future research, that is, larger sample size is a must, and class observation accompanied with interview could be adopted in order to get more findings.

\section{ACKNOWLEDGMENT}

This work was supported by Hubei Provincial Department of Education under Grant 13d044 and Wuhan Institute of Technology under Grant X2013031.

\section{REFERENCES}

[1] J. Burton, "Reflective practice"[A], In A. Burns \& J. C. Richards(eds), The Cambridge Guide to Second Language Teacher Education [C], Cambridge: Cambridge University Press, 2009, pp. 298-307.J. Clerk Maxwell, A Treatise on Electricity and Magnetism, 3rd ed., vol. 2. Oxford: Clarendon, 1892, pp.68-73.

[2] T. B. Corcoran, Teaching matters: How state and local policymakers can improve the quality of teachers and teaching, Philadelphia: Consortium for Policy Research in Education, 2007, pp.81-101.K. Elissa, "Title of paper if known," unpublished.

[3] C. Day, P. Sammons, G. Stobart, A. Kington, \& Q. Gu, Teachers matter: Connecting work, lives and effectiveness, Berkshire: Open University Press, 2007, pp158-179.

[4] T. S. C. Farrell, Reflective practice in the professional development of teachers of adult English language learners Retrieved, 15, March, 2010, from www.cal.org / caelanetwork / resources / reflectivepractice.html, 2008.

[5] D. M. Kagan, "Teacher's workplace meets the professors of teaching: A chance encounter at 30,000 feet", Journal of Teacher Education, Vol.41, No.4, pp.46-53, 1990.

[6] D. Richter*, M. Kunter, U. Klusmann, O. Lüdtke, J. Baumert, "Professional development across the teaching career: Teachers' uptake of formal and informal learning opportunities", Teaching and Teacher Education, Vol. 27, PP. 116-126, 2011.

[7] T. Russell, S. McPherson, A. K. Martin, "Coherence and Collaboration in Teacher Education Reform", Canadian Journal of Education, Vol. 26, No.1, pp.37-55, 2001.

[8] S. Veenman, "Perceived problems of beginning teachers", Review of Educational Research, Vol.54, No.2, pp.143-178, 1984 